Please cite as:

LETOURNEUX C., PÉTILLON J.-M. (2008) - Hunting lesions caused by osseous projectile points: experimental results and archaeological implications. Journal of Archaeological Science, 35 (10): 28492862. doi:10.1016/j.jas.2008.05.014

\title{
Hunting lesions caused by osseous projectile points: experimental results and archaeological implications
}

\section{Claire Letourneux}

Max-Planck Institute for Evolutionary Anthropology, department of human evolution, Deutscher Platz 6, D-04103 Leipzig, Germany

Jean-Marc Pétillon

Laboratoire Archéologies et Sciences de l'Antiquité, département d'ethnologie préhistorique, Maison René Ginouvès, boîte 22, 21 allée de l'Université, F-92023 Nanterre, France

\begin{abstract}
The identification of projectile impact traces on archaeological faunal remains is an important issue for understanding prehistoric hunting behavior, especially in the Paleolithic and Mesolithic. From the beginning of the Upper Paleolithic in Europe, and earlier in Africa, projectiles tipped with osseous points were of great importance for subsistence; but thus far, no specific experimental reference has been developed to help identify the traces left by these points. In 2003 and 2004 two series of projectile experiments with antler points of Magdalenian design were organized, involving two ox calves and two female fallow deer as targets for bow and spearthrower shooting. The subsequent study demonstrates that positive identifications of impact traces left by osseous points can be made. The observation of 127 impact traces allowed us to distinguish three main types of traces: notches, punctures and perforations. The relationships between the nature of the impact traces and the (i) the target species, (ii) characteristics of the impacted bones, and (iii) type of weapon are presented. Synthesized results are then discussed within the context of the European Upper Paleolithic and Mesolithic.
\end{abstract}

\section{Keywords}

Experimental archaeology; projectile; osseous points; hunting; impact traces on bone.

\section{Introduction}

In a recent article, M.J. Smith and colleagues (2007) pinpoint the lack of recognition of projectile trauma in archaeological bone material. In order to solve this problem, they provide valuable experimental data intended to maximize the identification of point impact traces. However, their work focuses on damage done by lithic points, an approach adopted by almost all previous authors who published similar experimental 
results (e.g., Morel, 1993, 2000). But even in pre-metallurgy cultures, stone is not the only material used to tip projectiles: osseous points made of bone, antler or ivory also played a significant role in the prehistoric weapon kit. In Europe, osseous projectile tips are absent from the Lower and Middle Paleolithic record (Villa and d'Errico, 2001), but become widespread from the inception of the Upper Paleolithic on (Knecht, 1993); in South Africa, the first evidence of this technology might date the Middle Stone Age (d'Errico and Henshilwood, 2007; Henshilwood et al., 2001).

The two types of projectile tips, lithic and osseous, show very contrasted structural and mechanical properties. While the stone varieties used to manufacture projectile points are usually isotropic, brittle and able to hold a sharp edge, points made of osseous tissues are anisotropic, much more resilient and have less cutting abilities (Knecht, 1997; Ellis, 1997). It can therefore be reasonably hypothesized that the impact traces made by the two types of points will differ in some respects.

In this perspective, identifying the lesions left by osseous points requires a specific experimental frame of reference, the lack of which would significantly limit our assessment of projectile traces for certain periods. This is particularly true for some European Upper Paleolithic cultures, such as the Aurignacian or the Magdalenian, where osseous points predominate over lithic ones in the archaeological record (Cattelain, 1995; O'Farrell, 2004). Constructing this frame of reference was undertaken by the present authors in 2003 and 2004, as a part of a broader experiment organized with P. Cattelain (Université Libre de Bruxelles / CEDARC, Musée du Malgré-Tout), and intended to explore the performance of Magdalenian antler points (Pétillon, 2005, 2006). Although portions of the results have previously been published (Pétillon and Letourneux, 2003-2004, in press), the complete study of the impact traces on bone, are presented here.

\section{Archaeological context: hunting traces on Paleolithic faunal material}

M.J. Smith et al. (2007: 541) convincingly argue that in regard to human bones, the lack of recognition of projectile trauma is likely to alter "inferences concerning the presence or absence of both intergroup and interpersonal conflict" in ancient societies, and thus "have significant implications for our understanding of conflict in prehistory". However, the authors elaborate less on the consequences of this methodological "myopia" for the interpretation of faunal remains. Still, although faunal remains bearing traces of projectile impact have long attracted the attention of archaeologists (e.g., NoeNygaard, 1974), the search and identification of these traces have often been of a nonsystematic nature, and concentrated on the most spectacular specimens and/or the best preserved collections (see survey by Cordier, 1990). We believe that looking for hunting impacts should be part of a zooarchaeologist's routine procedures, along with looking for other anthropogenic traces such as cut marks and percussion marks.

Hunting lesions can provide new insight on common zooarchaeological problems such as determining the origins of the archaeological bone accumulation, or identifying the methods of capture employed by the hunters. This statement especially applies to the Paleolithic and Mesolithic periods, when hunting and scavenging were the only ways 
for human groups to have access to animal resources, and for which the understanding of hunting methods is therefore the most crucial to reconstruct human behavioral patterns.

The very existence of hunting during the Lower and the Middle Paleolithic has long been a major issue of prehistoric research (for a review see Dominguez-Rodrigo, 2002; Dominguez-Rodrigo and Pickering, 2003; Stiner, 2002). In this context, faunal remains bearing traces of weapon impacts can be used as key arguments in the discussion, providing precious direct evidence of hunting activities. Good examples include the horse scapula from the Lower Paleolithic site of Boxgrove (United Kingdom), showing a possible projectile lesion (Bergman et al., 1999); and the wild ass vertebra from Umm el Tlell (Syria) with an embedded Levallois point fragment (Boëda et al., 1999), attesting to the use of lithic hunting weapons in the Middle Paleolithic.

For the Upper Paleolithic, projectile impact traces have played an important role in the issue of whether or not certain species were among the game hunted by humans. The existence of active mammoth hunting by human populations from the Siberian Upper Paleolithic was demonstrated by the discovery of a mammoth vertebra showing a perforation left by a composite projectile point (Maschenko et al., 2003; Zenin et al. 2006). Considering that the feasibility of mammoth hunting at that time has been repeatedly debated (Haynes, 1991; Bratlund, 1999; Praslov in Maschenko et al., 2003), this find sheds new light on the question of mammoth procurement techniques (e.g. hunting vs. scavenging). Similarly, bear hunting in the Upper Paleolithic, which has been questioned for many decades (for a review see Armand, 2006), is unquestionably attested by at least two specimens: the late Upper Paleolithic brown bear from the Grotte du Bichon, Switzerland, found with fragments of a flint point embedded in one of his vertebrae (Morel, 1998); and a similar find from Hohle Fels, Germany (Münzel and Conard, 2004).

These examples provide a glimpse of the interpretative potential of weapon impact traces on faunal material. Their more systematic recognition and documentation might significantly enlarge the number of specimens, which in turn might prove useful in the interpretation of faunal assemblages, especially in specific contexts. For instance, European Paleolithic cave and rockshelter sites are often characterized by a mixed occupation by both humans and large carnivores. In this case, distinguishing faunal remains left by human hunting from those accumulated by carnivores is a primary concern for zooarchaeologists (Brugal et al., 1997; for a review see: Pickering, 2002; Dominguez-Rodrigo and Pickering, 2003). Impact traces could contribute to this discussion by indicating the primary acquisition of some of the animals by humans.

In the most favorable situations, repeated observations could even give indications about the hunting methods employed. For example, the over-representation of impact traces on one bone type or body part might give a hint of the hunters' preferred target point. In Bratlund's (1990) exemplary study of the Late Upper Paleolithic sites of Meiendorf and Stellmoor, differences in the frequency, location and orientation of impact traces on reindeer bones between the Hamburgian and the subsequent Ahrensburgian could be interpreted as evidence of a shift from individual to more collective hunting techniques. 
With these perspectives in mind, the results presented below seek to improve the recognition of lesions left by osseous points on faunal material, through the development of an adequate experimental reference.

\section{Previous experimental work}

Projectile experiments involving the replication and use of prehistoric osseous weapon tips started in the 1980s, became more widespread in the next decade and declined after the end of the 1990s (see complete survey in Pétillon, 2006). The points used in these experiments included such diverse designs as Aurignacian split-based points (Knecht, 1993; Nuzhnyi, 1998), Solutrean self-barbed points (Pokines and Krupa, 1997), Magdalenian single- and double-beveled points (Arndt and Newcomer, 1986; Guthrie, 1983; Pokines, 1998; Stodiek, 1993), Upper Paleolithic bipoints from Syria and Lebanon (Arndt and Newcomer, 1986; Bergman, 1987) and bone points from the Folsom cultural complex (Frison and Zeimens, 1980). The projectiles were shot with a bow or crossbow, thrown with a spearthrower or hurled by hand against targets that were either portions of carcasses or complete carcasses of animals ranging in size from sheep/goat to domestic cow. However, in all cases, the main focus of the experiment was to test the functional characteristics of the points: hafting solidity, depth of penetration in the target, impact resistance and diagnostic impact traces on the points. Descriptions of damage to the targets' bones are usually lacking.

To our knowledge, the single exception is the experiment undertaken by Stodiek in 1990 (Stodiek, 1991, 1993, 2000). During this experimental session, 28 spears were hafted with replicas of Magdalenian single- and double-beveled reindeer antler points. Each of the spears (total length: $165 \mathrm{~cm}$; diameter: $1 \mathrm{~cm}$; mean weight: $81 \mathrm{~g}$ ) was then shot once with a crossbow calibrated to reproduce the mean delivery velocity of a spearthrower (estimated at $30 \mathrm{mps}$ for a $80 \mathrm{~g}$ spear). The target, placed at a distance of $15 \mathrm{~m}$, was the carcass of a 10-year-old female fallow deer (Dama dama). The shots were directed at the neck, shoulder, thorax and abdomen, thus avoiding the head, limb and hip bones.

Although the Stodiek's main concern was to test the effectiveness and durability of antler points vs. stone points, he also recorded the types of damage inflicted by antler points to the bones of the target. Three types of damage were described (Stodiek, 1991: 255; 1993: 206; 2000: 76). On flat, thin bones such as the upper part of the scapula, impact generally resulted in the projectile piercing the bone and leaving a round hole slightly larger than the projectile's diameter. Several impacts on flat bones with greater thickness, such as the largest processes of the thoracic vertebrae, caused the distal part of the point to pierce the bone and start a longitudinal split that could sometimes break the vertebral process in half. Finally, two spears hit the spinal arc of a vertebra, both impacts resulting in shallow penetration of the point $(\mathrm{ca} .2 \mathrm{~cm})$ and embedding of the point's distal fragment in the bone. This induced small cracks starting from the hole, though without splintering the vertebra. 
These observations suggest that all things being equal, the type and extent of the damage done by osseous points will vary according to the thickness and morphology of the impacted bone. Our objective was to test these preliminary results by experimenting on a larger sample and assessing the possible influence of other parameters.

\section{The experiment}

\subsection{The Isturitz archaeological reference}

The experiment was undertaken as a part of one of the authors' Ph.D. dissertation (Pétillon, 2006) addressing the technology of osseous projectile points from the Upper Magdalenian of the Isturitz cave (Pyrénées-Atlantiques, France). The Isturitz Upper Magdalenian layer, I/F1, was $5-60 \mathrm{~cm}$ thick and covered the entirety of the cave's largest chamber $\left(800-900 \mathrm{~m}^{2}\right)$. This layer was completely excavated between 1912 and 1937 (Passemard, 1924, 1944; Saint-Périer, 1936, 1947) and the majority of archaeological material is curated in the Musée d'Archéologie nationale (SaintGermain-en-Laye, Yvelines, France). Reindeer antler projectile tips are the most common artifact type among the osseous industries. The 705 pieces include 419 forkbased points, 122 double-beveled points, five nearly complete foreshafts, 38 possible foreshaft fragments and 121 typologically unidentified fragments. The primary goal of the experiment was to explore the performance of these types of projectile tips (Pétillon, 2005, 2006). The experimental protocol was thus devised to reflect the characteristics and the probable operating conditions of this material during the Upper Magdalenian.

\subsection{Experimental protocol}

The experiments were organized with Cattelain and took place at the CEDARC / Musée du Malgré-Tout (Treignes, Belgium), in four separate shooting sessions in January 2003 (two sessions) and February 2004 (two sessions).

Forty-two fork-based points, which were the main type represented in the archaeological assemblage, were manufactured and used in 2003, and an additional 36 in 2004. The 2004 sessions also included the manufacture and use of 18 double-beveled points and four foreshafts (the latter hafted in combination with the fork-based points). All points and foreshafts were taken from antler cortex rods-the raw material coming from Fennoscandian reindeer herds-and shaped with flint burins to reproduce the dimensions of the archaeological collection (Table 1).

The next step was to select a projectile delivery mode. The dimensions of the points (Table 1) did not allow their immediate classification as either arrowheads or tips of atlatl-propelled spears, as there is a dimensional overlap between the two categories and the points from our sample fall within the metric range of artifacts that could have been used to tip both types of projectiles (Cattelain, 1997; Hughes, 1998). The use of the spearthrower is evidenced during the Lower and Middle Magdalenian by the wellknown antler spearthrower hooks from France, Germany and Spain, but these artifacts are all but absent in Upper Magdalenian context (Cattelain, 2005). Conversely, no indisputable evidence of the use of the bow exists for this early period. The wooden

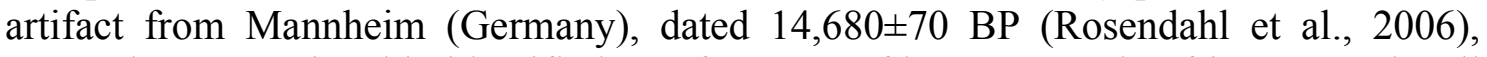
cannot be unquestionably identified as a fragment of bow. In South Africa, L. Backwell 
and colleagues (2008) suggest the existence of a bow and arrow technology as early as the Middle Stone Age (Howiesons Poort technocomplex); but this hypothesis is extremely uncertain because it is based on a very small archeological assemblage (two fragmentary bone points from Peers cave and Sibudu cave) and only on indirect evidence (the slender dimensions of the artifacts, pointing to an identification as arrowheads), without sufficient consideration of alternative possibilities (especially, no morphometric comparisons with ethnographic spear and dart heads were made). To date, the oldest definite direct evidence of the use of the bow is still the large collection of Ahrensburgian pine arrowshafts from Stellmoor, Germany (Rust, 1943), two millennia younger than the end of the Upper Magdalenian (Fischer and Tauber, 1986). This puzzling situation led us to consider experimenting with both types of weapons.

A portion of the points was thus hafted to arrow shafts and another part to spear shafts. The shafts were made from pinewood, which was inferred from the palynological data to be the most available species near Isturitz during the Upper Magdalenian period (Leroi-Gourhan, 1959). Secure hafting was achieved using hide glue, plus lashing with bison or red deer sinew (Figure 1). Characteristics of the projectiles are summarized in Table 2.

Regarding the target, the most appropriate species would have been reindeer, which is the dominant game in the Isturitz Upper Magdalenian (Letourneux in Pétillon et al., in press). However, since reindeer carcasses were not available, we used two ox calves, a few weeks old (in 2003) and two adult female fallow deer (in 2004). The calves came from a cattle farm and were slaughtered under veterinary control; the fallow deer came from an breeding park and were shot as a part of culling operations. In both cases, the animals were killed less than one hour before the beginning of the experimental session. The carcasses were complete and were not subject to any treatment such as freezing, skinning, evisceration, partial defleshing, etc.

The carcasses were loosely suspended in a lifelike position to a wooden bracket set up on a grassy meadow, with one side facing the experimenters. The ambient temperature was from $-5 /-10^{\circ} \mathrm{C}$ (in 2003) to $+5 /+10^{\circ} \mathrm{C}$ (in 2004). The shooting distance varied from 10 to 13 meters; these distances were considered consistent with ethnographic information on spearthrower and bow hunting, where "in any case... the hunter attempts to approach game as closely as possible" before shooting (Cattelain, 1997: 230; see also Hutchings and Brüchert, 1997).

All projectiles were then shot with bow or spearthrower. The bow was made by Tinnes following the design of Neolithic specimens from German sites; this self bow was made from yew, $177 \mathrm{~cm}$ long, with a draw length of $68.6 \mathrm{~cm} \mathrm{(27")} \mathrm{and} \mathrm{a} \mathrm{draw} \mathrm{weight} \mathrm{of} 27.9$ $\mathrm{kg}(61.5 \mathrm{lbs})$. For the spearthrower sessions, several spearthrowers were used, all of which were approximately $50-70 \mathrm{~cm}$ in length with wooden handles and an antler distal part ("hook") inspired by the design of Magdalenian specimens. The bow and spearthrower users (bow: Cattelain; spearthrower: Chauvaux, Cattelain, Demoulin, Rivère) were all experimented practitioners, regularly engaged in public demonstrations and in spearthrower and traditional bow competitions organized in Europe since the 1980s. 
In order to be able to distinguish arrow impacts from spear impacts, each animal was shot with one weapon only. In other words, we had one calf and one fallow deer shot with the bow, and one calf and one fallow deer shot with the spearthrower. To be more consistent with a realistic hunting situation, the bow and spearthrower users sought to direct the projectiles at the body part most likely to be aimed at by a hunter: the thorax behind the front limb, corresponding to the vital organs of heart and lungs (NoeNygaard, 1974).

Each arrow or spear was shot repeatedly until the point, shaft or hafting was damaged. A total of 618 shots were performed, 455 of which hit the target. Each impact was photographed and its characteristics were recorded on a form. Each daily shooting session lasted between 2.5 and 3.5 hours and was centered on one animal. Each carcass was processed immediately after each session, in order to recover all point fragments and to study the impact traces on the bones. The butchery was conducted with stone tools, and the processed bones were then vacuum packed. Once back in France, they were properly cleaned by boiling in water to detach the remaining meat, cartilage, etc. The defleshing was then finished using the same stone tools. Finally, the bones were dried in the open air and individually packed.

\section{Results}

Among the 455 shots hitting the target, many penetrated the animal's hide or impacted the muscles or the viscera without touching a bone. It must also be noted that in the 2004 session, the accumulation of very numerous impacts on the same ribs caused several ribs to splinter into many small fragments. These fragmented up rib portions were excluded from all counts, as they result from a "relentless shooting of the same target" that has nothing to do with a realistic hunting situation. Despite these exclusions, a total of 127 impact traces could be counted on the bones of the four carcasses (Table 3). More than $70 \%$ of the impact traces are concentrated in a zone encompassing the scapula, thorax (ribs, sternum, thoracic vertebrae) and the lumbar vertebrae: this reflects the aiming instructions.

\subsection{Typology of the traces}

The impact traces left by the antler points were characterized and recorded by types, in order to construct a "catalog" of the diagnostic marks that would allow their identification in archeological faunal material. The bones were only examined with the naked eye and under low magnification (x10), because our purpose was to allow the recognition of projectile impact marks among large collections of archaeological material without having to observe each single faunal remain under high magnification, which would have been impossible in practical conditions. The categories of marks are presented in Tables 4-7.

Our terminology is derived from the one proposed by P. Morel (1993) for impact traces of Solutrean lithic points. Our own observations led us to reorganize the description criteria, distinguishing three types of damage:

- notches (éraflures) occur when a point grazes a bone and tears off a small amount of material from one of its sides (Figure 2); 
- punctures (percements) are made by the tip of the point when it impacts the bone without going through (Figure 3); and

- perforations (transpercements) apparently correspond to the damage designated as "full thickness puncture" by Smith et al. (2007). It is indeed a "complete puncture": the point went through the bone and caused a hole (Figure 4).

Two secondary marks can also be observed and are mostly related to punctures and perforations:

- Embedding (incrustation): after each shooting session, several points or distal point fragments remained inserted inside the target. Some of these could be extracted during carcass processing, but others stayed literally embedded in a bone and could not be retrieved without destroying them (Figure 5). These damages were thus recorded as either punctures or perforations, with the added feature that the point (or a part thereof) was fixed in the hole.

- Crack (fissuration): these spread from the impact point along the osseous fibres, and can cause the splintering of the smaller bones (Figure 6).

\subsection{Type of traces vs. type of animal}

On both animals, punctures are the rarest type of damage, while perforations are among the most frequent (Table 8). The fact that notches are more frequent on the fallow deer skeletons is likely related in part to the exclusion of the splintered rib fragments (see above), which probably caused several perforations to be excluded from the sample.

However, for certain types of bones, there is a sharp contrast between the two species (Table 9). On the calves' long bones, punctures and perforations are common and almost exclusive (8/9 traces), while on the long bones of the fallow deer, notches are the majority (3/5 traces). This situation is likely explained by differences in the bones' mineral content and, to a lesser degree, in the bones' morphology. The immature long bones of the calves, being much less mineralized and having wider shafts with flatter sides, were easily penetrated by the projectile points. In contrast, the long bones of the fallow deer, being sturdier, slimmer and having more rounded angles, proved surprisingly impact resistant. In the majority of impacts on these bones, the projectiles were simply deflected by the cylindrical diaphysis and the rounded reliefs of the extremities, leaving little or no macroscopic trace in the bone, while the projectile itself almost always suffered significant damage (Figure 7).

The frequency of point embeddings is also related to the bones' degree of mineralization. Embeddings are quite common in the calves' bones, but almost absent in the fallow deer (Table 10). The calves' immature skeletons behaved like true "point traps": the osseous fibres were elastic enough to allow penetration of the point, then tighten up around it and prevent its extraction. On the right scapula of the calf shot with the spearthrower, seven perforations resulted in three embeddings (Figure 5); while on the right scapula of the fallow deer shot with the bow, no point remained embedded despite five perforations. However, these five perforations caused several cracks that splintered the scapula (Figure 8), while the calf scapula remained in one piece because of its higher elasticity. 
Cracks, on the contrary, frequently occur with punctures and perforations whatever the bone's degree of mineralization (Table 11).

\subsection{Type of traces vs. type of bone}

When comparing the type of bone struck and the type of impact trace (excluding the head, for which the sample is too small), two separate groups emerge (Table 11). The first one includes the vertebrae, ribs, sternum and innominate, where notches are the most common damage. The second group comprises the scapula and long bones, in which perforations dominate. However, we have seen that most perforations on long bones were found on the calves' skeletons, and that this high frequency could be explained by the lower mineralization of these bones. If we exclude the calves' long bones from the sample, it appears that the most prominent contrast is between the scapula and all other bones. The scapula is closely linked to perforation damage, which is not surprising given its flat shape and shield-like position on the animal's side. Even the four shots that went through the animal's carcass and hit the opposite scapula from its medial side caused a perforation.

\subsection{Type of traces vs. type of weapon}

There is a vast literature on the mechanics and performance of bow and spearthrower (see survey in Bergman et al., 1988; Hutchings and Brüchert, 1997) and a detailed review of these are beyond the scope of this article. For the purpose of this discussion, it must be noted that the kinetic energy of spearthrower-launched projectiles was found to be generally superior to that of arrows fired with traditional self bows: kinetic energy being a function of mass and velocity, the much higher mass of most spearthrower projectiles more than makes up for their lower delivery velocity (Hutchings and Brüchert, 1997).

Gross estimates of impact energies of our own experimental projectiles support this argument, although no velocity measurements could be taken during our experiments. The comparative data provided by Stodiek (high-speed camera velocity measurements: Stodiek, 1993, Figure 189-190) indicate that at a 10-13 m shooting distance, a spearthrower projectile will hit its target at about $25.2 \mathrm{mps}$, while an arrow fired with a traditional self bow will reach 37.6 mps. The mean mass of our experimental spears and arrows being $0.1787 \mathrm{~kg}$ and $0.0325 \mathrm{~kg}$, respectively, the mean kinetic energy of the impacts can be estimated as follows:

$E_{k}=1 / 2 m v^{2}$

where $E_{k}$, kinetic energy (joules); m, mass $(\mathrm{kg})$; and v, velocity $(\mathrm{m} / \mathrm{s})$.

For spears : $\mathrm{E}_{\mathrm{k}}=0.5 \times 0.1787 \times 25.2^{2}=56.74$

For arrows : $\mathrm{E}_{\mathrm{k}}=0.5 \times 0.0325 \times 37.6^{2}=22.97$

The results suggest that spear impacts have approximately 2.5 times the kinetic energy of arrow impacts; since the values for velocity are only estimates, this number must not be regarded as a precise calculation but only as a plausible order of magnitude. One of our concerns was to determine if this difference resulted in distinct impact trace patterns on the bones of the target. However it appears that when comparing impacts on similar bones of similar animals, spears and arrows caused the same type of impact traces 
(Tables 4-7). The only difference was observed on the fallow deer skeletons, specifically on the impacts in the vertebrae, ribs and sternum: in these bones, while arrow impacts caused mostly notches, spear impacts produced a more varied range of traces, the total of punctures plus perforations being the majority. It might be suggested that the "lighter" arrow impacts were more easily partially deflected by the lateral side of the bones, thus causing a scarcity of punctures and perforations.

\section{Discussion}

\subsection{Summary}

Our experimental results demonstrate that the lesions caused in bones by osseous projectile points can be:

- notches: the most common type of impact trace on all bones except the scapula; and

- punctures and perforations: the shape of which fits the cross-section of the point, and that can be associated with cracks and/or embedded fragments. The latter phenomenon is very rare, at least on bones of adult individuals.

Another finding of this study is that the nature and frequency of the traces are likely to be influenced by the morphology and dimensions of the impacted bone. Therefore, we emphasize that the pattern described above might be valid for animals with approximately the same build as our experimental targets, but must not be applied without modification to other species, especially adult large ungulates (e.g. horse, bovines, etc.). For these, a specific experimental reference still needs to be developed.

The comparison between the 2003 and the 2004 sessions also shows that a bone's density and degree of mineralization will definitely condition its reaction to projectile impact. Bones from juvenile individuals-especially the long bones-are more likely to be pierced by an osseous point and retain it embedded.

All these conditioning parameters could be referred to as "intrinsic", in that they depend on the characteristics of the target itself. "Extrinsic" parameters include the features of the hunting equipment (weapon, projectile and point) and the hunting situation (angle and distance of the shot). Their influence was not systematically tested during our experiment. It was nonetheless observed that all things being equal no qualitative difference occurred between bone lesions caused by arrows shot with a bow and those made by heavier projectiles propelled with a spearthrower; only at the statistical level, the ratio of the types of traces (notches vs. punctures + perforations) appears different for certain types of bones. But this parameter undoubtedly deserves further testing.

All our experiments and all previous experiments by Stodiek were made exclusively with antler points: thus the raw material of the osseous points-antler, bone or ivory-is another "extrinsic" parameter that was not tested. However, these three osseous materials share overall similar properties (anisotropy, resilience, lesser cutting ability compared to flint: Ellis, 1997) and there is no reason to think that their effects on bones will be extremely different.

\subsection{Comparison between traces left by osseous and lithic points}


From the published data (Morel, 2000; Smith et al., 2007), it appears that impact traces left by osseous and lithic points fall into the same general categories (notches, punctures, perforations), which is not surprising since the type of target and the mechanics of impact are basically the same. But in most cases, obvious differences are also visible. Since the shape of punctures and perforations tends to reflect the crosssection of the point, traces left by osseous points will be rounded or oval and have rounded edges (Figures 4-6), while lithic points will leave more elongated traces with sharper edges (Smith et al., 2007, fig. 3-6). However, Morel also published several perforations left on vertebrae by experimental Solutrean shouldered points: these traces have a relatively rounded cross-section and could be confused with impacts made by osseous points (Morel, 2000, fig. 3-5). A systematic experiment is still needed including osseous, lithic and composite projectile tips used in similar shooting conditions, in order to build a comparative referential of impact traces. As long as this referential is not available, caution must be exerted when interpreting the type of point used from the morphology of the impact trace, unless of course this trace contains an embedded tip fragment.

\subsection{Projectile hunting lesions in archaeological context}

We examined the 575 faunal remains from the Isturitz Upper Magdalenian (layer I/F1, Passemard and Saint-Périer excavations), looking for all possible impact traces, using our experimental collection as a reference. This faunal assemblage was chosen because it was associated with the osseous points from which our experimental projectiles were made. However, the archeological context of this faunal assemblage is not favorable to the discovery of impact traces due to the site's excavation and post-excavation history (Pétillon et al., in press). The majority of the Upper Magdalenian fauna from the Passemard collections was actually lost after the excavations; and during the SaintPérier excavations in the 1920s and 1930s, the collection of faunal remains was clearly oriented towards easily identifiable specimens such as teeth, epiphyses, carpal and tarsal bones, resulting is a biased assemblage in which the bones most prone to bearing impact traces (e.g., scapulae, vertebrae and ribs) are in small number.

However, despite these limitations, one impact trace was identified. The specimen is a rib fragment $(91.6 \times 15.0 \times 8.2 \mathrm{~mm})$ from a medium-sized ungulate, with a notch on one side (Figure 9). The notch is $13.3 \times 2.6 \mathrm{~mm}$, and closely resembles the experimental damage created by osseous points. It shows internal bevelling on the lateral side, indicating that the rib was hit from its medial side (Smith et al., 2007), indicating indirectly the projectile's depth of penetration through the animal's body. The main conclusion from this first test is that if an impact trace can be identified even in this small biased collection from Isturitz, much more can be expected from larger, wellpreserved collections with a less selective sampling of faunal remains. That said, special attention should be given to the recognition and documentation of such traces on faunal assemblages overall.

An additional implication of our research is that projectile impacts are a concern not only to the zooarchaeologist, but also to the bone tool specialist. Worked bone items can also display impact traces, as shown by the two following examples identified during cursory examinations of Magdalenian osseous industries at the Musée d'archéologie nationale. The first specimen, from the Middle Magdalenian of the salle de Saint-Martin 
at Isturitz (layer SI), involves the left scapula of a deer used as a core for the manufacture of two bone discs (rondelles; Figure 10). An oval perforation, $15.7 \mathrm{x}$ $11.8 \mathrm{~mm}$, is located on the supraspinous fossa and shows internal bevelling on the lateral side. This trace is very similar to experimental perforations made in scapulae by osseous projectile points. The second specimen is from the Upper Magdalenian of La Vache cave (Ariège, France) and involves an awl manufactured by scraping the distal extremity of an ulna (Figure 11). Its caudal margin bears a notch, 9.8 × $2.0 \mathrm{~mm}$. This notch is very similar to the one noticed on the Isturitz rib fragment mentioned above, and probably reflects a similar origin, a projectile impact. It is worth noting that both items were published (Saint-Périer, 1930; Buisson, 2004) and that their particular features were erroneously described as intentionally manufactured features but not interpreted as possible impact traces.

Several authors have emphasized the small numbers of projectile impact traces on Paleolithic and Mesolithic faunal material (e.g., Morel, 1993; Stodiek, 1993). In order to test this assertion, we systematically searched for these traces in the archeological literature. Although this survey focused on the Upper Paleolithic and Mesolithic of Europe and Russia, we believe that the following discussion has relevance for other hunter-gatherer archeological contexts as well.

The choice of this focused survey was prompted by the fact that these regions and periods had been the most intensively studied from this particular point of view. However, adding our own references to the data collected by Noe-Nygaard (1974) and Cordier (1990), we counted no more than 74 published impact traces (Table 12). Sixty cases $(81 \%)$ are concentrated in Denmark and northern Germany, with $32(43 \%)$ for the site of Stellmoor alone. According to Morel (1993: 56), one of the reasons for this rarity could be that "impacts on bone are a minority because they are involuntary": the hunters aimed at the animal's vital organs and likely tried to avoid hitting the bones of their targets. However, we have seen that when directing a projectile at the "heart/lungs" zone, a slight deviation is enough to hit the proximal part of the humerus, scapula, a vertebra or a rib. In a prehistoric hunting situation, these events would undoubtedly have been common, and did not necessarily result in a hunting failure (even when a bone is hit, a wound in this part of the body is serious enough to hamper the animal). Thus the low frequency of impact traces in the archaeological record deserves another explanation.

Bovines, cervids and suidae can harm each other, especially males during rutting fights, but the traces left on the bones by such activities are likely to be superficial (pits, furrows) and centered on the head (Noe-Nygaard, 1974). On the contrary, as demonstrated above, projectile impact traces are most frequent on the bones of the thorax and attest to a full piercing of the skin and a deep penetration in the animal's body. It is therefore unlikely that zooarchaeologists mistake human hunting traces for naturally occurring wounds.

As Morel (Morel, 2000) suggests, preservation factors certainly play an important role, e.g. the thin blade of the scapula, the fragility of ribs and the vertebrae. Their shape also makes them more susceptible to fragmentation, but above all the low density of some of their portions makes them highly vulnerable to post-depositional bone attrition (Lyman, 
1994; Lam et al., 1998, 1999; Lam and Pearson, 2003, 2004). They are also among the parts most likely to be eaten by carnivores (Blumenschine and Marean, 1993) and/or consumed by humans for a variety of needs. To a large extent, these factors probably account for the scarcity of impact traces on archaeological faunal material. They might also explain the higher concentration of impact traces in the Mesolithic and Final Paleolithic bog sites of northern Europe, where the preservation of osseous material is optimal, the involvement of carnivores often minimal, and butchery activities sometimes completely absent (finds of isolated animals: cf. Noe-Nygaard, 1974).

However, a comparison between the published archaeological traces and our experimental results shows that other factors must also be considered. The large majority of the published traces display embedded tip fragments, either lithic or osseous, visible macroscopically or under low magnification (i.e. magnifying lens). These traces are indeed the ones whose identification as projectile impacts is the most certain (for example, Bratlund, 1990, explicitly limits her study to these traces in order to exclude all dubious specimens from the sample). But our experimental results with osseous points show that tip embeddings are actually a minority of impact traces: $24.5 \%$ on the juvenile calves (12/49), and $1.3 \%$ on the adult fallow deer (1/78: Table 10).

In regards to lithic points, experiments with the TFPS group (Solutrean flint points shot with a bow, crossbow or spearthrower into carcasses of adult goats), led Morel (1993) to conclude that embeddings represent "about 20\%" of the 241 impact traces-in other words, about $80 \%$ of the traces do not display such features. On a smaller sample of 32 impacts, Smith and colleagues (2007) report a higher percentage of $44 \%$ traces with embedded fragments. However, this total includes "many cases" of microscopic fragments not observed macroscopically; it might also have been increased by the experimental protocol they used (see below).

Another factor increases this bias. All published impact traces are either punctures or perforations, while notches are never mentioned. However, we demonstrated that experimentally, notches are the most frequent type of damage left by osseous points on all bones except the scapula (Table 11). In regard to lithic point impacts, Morel (2000: 55) states that notches "are present on all bone types and are frequent on vertebrae and ribs". Smith and colleagues (2007) do not mention this type of damage, but we believe this is due to their experimental protocol that primarily included shots into cattle scapulae. Extended tests with a more varied sample of bone types might provide different results on this point. Overlooking these less conspicuous traces undoubtedly further reduces the assessment of impact traces on archaeological material.

Overall, it seems clear that archaeologists' focus on punctures and perforations displaying (macroscopic) imbedded tip fragments has led them to ignore the large majority of potential projectile traces on archaeological material, especially when osseous points are concerned. The traces that we found on the Isturitz and La Vache material emphasize that new analyses and reconsideration of ancient collections might yield a wealth of new evidence.

\section{Acknowledgments}


We most strongly thank Pierre Cattelain (Université Libre de Bruxelles, CEDARC/Musée du Malgré-Tout, Belgium), co-organizer of the 2003 and 2004 experiments. We also thank all the participants in the experiments, especially our spearthrower users, Pascal Chauvaux, Emmanuel Demoulin and Florent Rivère. Sincere thanks are extended to the staff from the Musée du Malgré-Tout (Belgium) for their logistical support. We are grateful to Sandrine Costamagno and Véronique Laroulandie for their comments on an earlier version of this paper, and to Laura Niven, Daniel Richter and three anonymous reviewers, whose suggestions and careful reading greatly improved the manuscript. We would like to acknowledge Catherine Schwab, curator of the Paleolithic Department of MAN (Saint-Germain-en-Laye, France), and her assistant Marie-Sylvie Larguèze for help with the collections. A first version of this work was presented at the workshop "La taphonomie: des référentiels aux ensembles osseux fossiles" held in Toulouse (France) in November 2005. We would like to thank the organizers of the workshop, Sandrine Costamagno, Philippe Fosse and Frédéric Laudet. The 2003 experiment was partly funded by the UMR 7041 ArScAn laboratory (Ethnologie Préhistorique Department; France) and the University Paris I PanthéonSorbonne (France). This paper was written while one of the authors (C.L.) was funded by a Marie Curie Intra-European Fellowship (EIF) and the second author (J.-M.P.) had a research grant of la fondation des Treilles.

\section{References}

Allain, J., 1952. Un coup de merlin préhistorique? Bulletin de la société préhistorique française 49, 26-29 and 199.

Arias Cabal, P., Ontañon Peredo, R., Álvarez Fernández, E., Aparicio, M.T., Chauvin, A., Clemente Conte, I., Cueto Rapado, M., González Urquijo, J.E., Ibañez Estévez, J.J., Tapia Sagarna, J., Teira Mayolini, L.C., 2005. La estructura Magdaleniense de La Garma A. Aproximación a la organización espacial de un hábitat paleolítico, in: Ferreira Bicho, N. (Ed.), O Paleolítico. Actas do IV Congresso de arqueologia peninsular. Universidade do Algarve, Faro, pp. 123-141.

Armand, D., 2006. Abri Castanet (Dordogne, France): An Aurignacian site with bear procurement. Bear exploitation in Paleolithic time. Scientific Annals - School of geology - Aristote University of Thessaloniki special volume 98, 263-268.

Arndt, S., Newcomer, M.H., 1986. Breakage patterns on prehistoric bone points, in: Roe, D.A. (Ed.), Studies in the Upper Paleolithic of Britain and Northwest Europe. Archaeopress, Oxford, pp. 165-173.

Backwell, L., d'Errico, F., Wadley, L., 2008. Middle Stone Age bone tools from the Howiesons Poort layers, Sibudu Cave, South Africa. Journal of Archaeological Science $35,1566-1580$.

Bergman, C.A., 1987. Hafting and use of bone and antler points from Ksar Akil, Lebanon, in: Stordeur, D. (Ed.), La Main et l'outil. Manches et emmanchements préhistoriques. Maison de l'Orient méditerranéen, Lyon, pp. 117-126. 
Bergman, C.A., McEwen, E., Miller, R., 1988. Experimental archery: Projectile velocities and comparison of bow performances. Antiquity 62, 658-670.

Bergman, C.A., Roberts, M.B., Wilhelmsen, K.H., 1999. Archaeology of excavated areas, in: Roberts, M.B., Parfitt, S.A. (Eds.), Boxgrove: A Middle Pleistocene Hominid Site at Eartham Quarry. English Heritage, London, pp. 312-378.

Blumenschine, J.R., Marean, C.W., 1993. A Carnivore's view of archaeological bone assemblages, in : Hudson, J. (Ed.), From Bones to Behavior. Center for Archaeological Investigations - Southern Illinois University, Carbonedale, pp.273-300.

Boëda, E., Geneste, J.-M., Griggo, C., Mercier, N., Muhesen, S., Reyss, J.L., Taha, A., Valladas, H., 1999. A Levallois point embedded in the vertebra of a wild ass (Equus africanus): Hafting, projectile and Mousterian hunting weapons. Antiquity 73, 394-402.

Boriskowski, P.J., 1965. Récents progrès des études paléolithiques en URSS. L'Anthropologie 69, 5-30.

Bouchud, J.,1975. Etude de la faune de l'abri Pataud, in: Movius, H.L. (Ed.), Excavation of the Abri Pataud, les Eyzies (Dordogne). Harvard University - Peabody Museum, Cambridge, pp. 69-153.

Bratlund, B., 1990. Rentierjagd im Spätglazial. Eine Untersuchung der Jagdfrakturen an Rentierknochen von Meiendorf und Stellmoor. Offa 47, 7-34.

Bratlund, B., 1999. Taubach revisited. Jahrbuch des Römisch-Germanischen Zentralmuseums Mainz 46, 61-174.

Brugal, J.-P., Fosse, P., Guadelli, J.L, 1997. Comparative study of bone assemblages made by recent and Plio-pleistocene Hyaenids (Hyaena, Crocuta), in: Hannus, L.A., Rossum, L., Winham, R.P. (Eds.), Proceedings of the 1993 Bone Modification Conference (Hot Springs, South Dakota). Archaeology Laboratory-Augustana College, Sioux Falls, pp. 158-187.

Buisson, D., 2004. Les poinçons, in: Clottes, J., Delporte, H. (Eds.), La grotte de la Vache (Ariège), I: Les occupations du Magdalénien. CTHS/RMN, Paris, pp. 331-334.

Castel, J.-C., 1999. Comportements de subsistance au Solutréen et au Badegoulien d'après les faunes de Combe Saunière (Dordogne) et du Cuzoul de Vers (Lot). Ph.D. Disseration, University Bordeaux 1.

Cattelain, P., 1995. Armatures de projectiles en pierre ou en matière dure animale: Un choix liée à l'environnement?, in: Otte, M. (Ed.), Nature et culture. Service de Préhistoire - Université de Liège, Liège, pp. 181-185.

Cattelain, P., 1997. Hunting during the Upper Paleolithic: Bow, spearthrower, or both?, in: Knecht, H. (Ed.), Projectile Technology. Plenum press, New York, pp. 213-240. 
Cattelain, P., 2005. Propulseurs magdaléniens: marqueurs culturels régionaux?, in: Dujardin, V. (Ed.), Industrie osseuse et parures du Solutréen au Magdalénien en Europe. Société préhistorique française, Paris, pp. 301-317.

Cordier, G., 1990. Blessures préhistoriques animales et humaines avec armes ou projectiles conservés. Bulletin de la société préhistorique française 87, 462-480.

d'Errico, F., Henshilwood, C.S., 2007. Additional evidence for bone technology in the southern African Middle Stone Age. Journal of Human Evolution 52, 142-163.

Dominguez-Rodrigo, M., 2002. Hunting and scavenging by Early Humans: The state of the debate. Journal of World Prehistory 16, 1-54.

Dominguez-Rodrigo, M., Pickering T.R., 2003. Early hominid hunting and scavenging: A zooarchaeological review. Evolutionary Anthropology 12, 275-282.

Ellis, C.J., 1997. Factors influencing the use of stone projectile tips: An ethnographic perspective, in: Knecht, H. (Ed.), Projectile Technology. Plenum press, New York, pp. 37-74.

Fischer, A., Tauber, H., 1986. New C-14 datings of Late Paleolithic cultures from northwestern Europe. Journal of Danish Archaeology 5, 7-13.

Frison, G.C., Zeimens, G.M., 1980. Bone projectile points: An addition to the Folsom cultural complex. American Antiquity 45, 231-237.

Guthrie, R.D., 1983. Osseous projectile points: Biological considerations affecting raw material selection and design among paleolithic and paleoindian people, in: CluttonBrock, J., Grigson, C. (Eds.), Animals and Archaeology, I: Hunters and their Prey. Archaeopress, Oxford, pp. 273-294.

Hallam, J.S., Edwards, B.J.N., Barnes, B., Stuart, A.J., 1973. The remains of a late glacial elk associated with barbed points from High Furlong, near Blackpool, Lancashire. Proceedings of the prehistoric society 39, 100-128.

Haynes, G., 1991. Mammoths, Mastodonts and Elephants. Cambridge University Press, Cambridge.

Henshilwood, C.S., d'Errico, F., Marean, C.W., Milo, R.G., Yates, R., 2001. An early bone tool industry from the Middle Stone Age at Blombos Cave, South Africa: implications for the origins of modern human behaviour, symbolism and language. Journal of Human Evolution 41, 631-678.

Hughes, S.S., 1998. Getting to the point: evolutionary change in prehistoric weaponry. Journal of Archaeological Method and Theory 5, 345-408.

Hutchings, W.K., Brüchert, L.W., 1997. Spearthrower performance: Ethnographic and experimental research. Antiquity 71, 890-897. 
Knecht, H., 1993. Early Upper Paleolithic approaches to bone and antler projectile technology, in: Peterkin, G.L., Bricker, H.M., Mellars, P. (Eds.), Hunting and Animal Exploitation in the Later Paleolithic and Mesolithic of Eurasia. Archaeological Papers of the American Anthropological Association, Washington, DC, pp. 33-47.

Knecht, H., 1997. Projectile points of bone, antler and stone: experimental explorations of manufacture and use, in: Knecht, H. (Ed.), Projectile Technology. Plenum press, New York, pp. 191-212.

Lam, Y.M., Chen, X., Marean, C.W., Frey, C., 1998. Bone density and long bone representation in archaeological faunas: comparing results from $\mathrm{CT}$ and photon densitometry. Journal of Archaeological Science 25, 559-570.

Lam, Y.M., Chen, X., Pearson, O.M., 1999. Intertaxonomic variability in patterns of bone density and the differential representation of bovid, cervid, and equid elements in the archaeological record. American Antiquity 64, 343-362.

Lam, Y.M., Pearson, O.M., 2003. Bone density studies and the interpretation if the faunal record. Evolutionary Anthropology 14, 99-108.

Lam, Y.M., Pearson, O.M., 2004. The fallibility of bone density values and their use in archaeological record. Journal of Taphonomy 2, 99-115.

Lartet, E., Christy, H., 1864. Sur des figures d'animaux gravés et sculptés et d'autres produits d'art et d'industrie rapportables aux temps primordiaux de la période humaine. Revue archéologique 41, 233-267.

Leroi-Gourhan, A., 1959. Résultats de l'analyse pollinique de la grotte d'Isturitz. Bulletin de la société préhistorique française 56, 619-624.

Lyman, R.L.,1994. Vertebrate Taphonomy. Cambridge University Press, Cambridge.

Maschenko, E.N., Pavlov, A.F., Zenin, V.N., Leshchinskiy, S.V., Orlova, L.A., 2003. The Lugovskoe site: relations between the mammoth assemblage and Late Paleolithic man, in: Abstracts of the Third International Mammoth Conference (Dawson City, Canada). http://www.yukonmuseums.ca/mammoth/abstrl-mas.htm\#41

Moirenc A., Cotte J., Cotte C., 1921. Une inclusion remarquable dans un os paléolithique. Revue des études anciennes, 23, 117-119.

Morel, P., 1993. Impacts de projectiles sur le gibier: quelques éléments d'une approche expérimentale, in: Anderson, P.C., Beyries, S., Otte, M., Plisson, H. (Eds.), Traces et fonction: Les gestes retrouvés. Service de Préhistoire de l'université de Liège, Liège, pp. $55-57$. 
Morel, P., 1998. La grotte du Bichon (La Chaux-de-Fonds, canton de Neuchâtel, Suisse), in: Les derniers chasseurs-cueilleurs du massif jurassien et de ses marges. Centre jurassien du patrimoine, Lons-le-Saunier, pp. 88-93.

Morel, P., 2000. Impacts de chasse et archéozoologie: Quelques observations expérimentales, in: Bellier, C., Cattelain, P., Otte, M. (Eds.), La chasse dans la Préhistoire. Société royale belge d'Anthropologie et de Préhistoire/Service de Préhistoire de l'université de Liège/Centre d'études et de documentation archéologiques, Bruxelles, pp. 54-59.

Münzel, S.C., Conard, N., 2004. Cave bear hunting in Höle Fels cave in the Ach Valley of the Swabian Jura. Revue de Paléobiologie 23, 877-885.

Noe-Nygaard, N., 1974. Mesolithic hunting in Denmark illustrated by bone injuries caused by human weapons. Journal of Archaeological Science 1, 217-248.

Noe-Nygaard, N., 1975. The shoulders blades with healed lesions from Star Carr. Proceedings of the Prehistoric Society 41, 10-16.

Nuzhnyi, D., 1998. The preliminary results of experiments with Aurignacian split based points production, hafting and usage. Préhistoire Européenne 13, 117-132.

O'Farrell, M., 2004. Les pointes de la Gravette de Corbiac (Dordogne) et considérations sur la chasse au Paléolithique supérieur ancien, in: Bodu, P., Constantin, C. (Eds.), Approches fonctionnelles en Préhistoire. Société préhistorique française, Paris, pp. 121138.

Passemard, E., 1924. Les stations paléolithiques du Pays Basque et leurs relations avec les terrasses d'alluvions. Bodiou, Bayonne.

Passemard, E., 1944. La caverne d'Isturitz en Pays Basque. Préhistoire 9, 7-95.

Pétillon, J.-M., 2005. Tir expérimental de pointes à base fourchue en bois de renne, in: Dujardin, V. (Ed.), Industrie osseuse et parures du Solutréen au Magdalénien en Europe. Société préhistorique française, Paris, pp. 243-256.

Pétillon, J.-M., 2006. Des Magdaléniens en armes. Technologie des armatures de projectile en bois de cervidé du Magdalénien supérieur de la grotte d'Isturitz (PyrénéesAtlantiques). Centre d'études et de documentation archéologiques, Treignes.

Pétillon, J.-M., Letourneux, C., 2003-2004. Au retour de la chasse... Observations expérimentales concernant les impacts sur le gibier, la récupération et la maintenance des projectiles dans le Magdalénien supérieur d'Isturitz. Préhistoire Anthropologie méditerranéennes 12, 173-188; 13, 133.

Pétillon J.-.M., Letourneux C., in press. Tirs expérimentaux au CEDARC en 2003 et 2004 : résultats de l'étude des traces d'impact sur le squelette des animaux-cibles. Annales de Paléontologie. 
Pétillon, J.-M., Letourneux, C., Laroulandie, V., in press. Archéozoologie des collections anciennes: Le cas de la faune du Magdalénien supérieur d'Isturitz, in: Normand, C. (Ed.), Les recherches archéologiques dans les grottes d'Isturitz et d'Oxocelhaya de 1912 à nos jours: Une synthèse des résultats. Paléo special issue.

Pickering, T.R., 2002. Reconsideration of criteria for differentiating faunal assemblages accumulated by Hyenas and Hominids. International Journal of Osteoarchaeology 12, 127-141.

Pokines, J.T., 1998. Experimental replication and use of Cantabrian lower Magdalenian antler projectile points. Journal of Archaeological Science 25, 875-886.

Pokines, J.T., Krupa, M., 1997. Self-barbed antler spearpoints and evidence of fishing in the late Upper Paleolithic of Cantabrian Spain, in: Knecht, H. (Ed.), Projectile Technology. Plenum press, New York, pp. 241-262.

Régnault, F., 1893. Une nouvelle halte de chasse à l'époque du renne près Saint-Lizier (Ariège). Revue des Pyrénées 5, 533-539.

Rosendahl, G., Beinhauer, K.W., Löscher, M., Kreipl, K., Walter, R., Rosendahl, W., 2006. Le plus vieil arc du monde? Une pièce intéressante en provenance de Mannheim, Allemagne. L'Anthropologie 110, 371-382.

Rust, A., 1943. Die alt- und mittelsteinzeitlichen Funde von Stellmoor. Neumünster, Karl-Wachholtz Verlag.

Saint-Périer, R. de, 1930. La grotte d'Isturitz, I: Le Magdalénien de la Salle de SaintMartin. Masson, Paris.

Saint-Périer, R. de, 1936. La grotte d'Isturitz, II: Le Magdalénien de la grande salle. Masson, Paris.

Saint-Périer, R. de, 1947. Les derniers objets magdaléniens d'Isturitz. L'Anthropologie 51, 393-415.

Sauter, M.R., 1985. Note sur deux objets magdaléniens de Veyrier, in: Eléments de Préet Protohistoire européenne, hommages à Jacques-Pierre Millotte. Les Belles lettres, Paris, pp. 97-103.

Schuler, A., 1994. Die Schussenquelle. Eine Freilandstation des Magdalénien in Oberschwaben. Komissionsverlag/Konrad Theiss Verlag, Stuttgart.

Smith, M.J., Brickley, M.B., Leach, S.L., 2007. Experimental evidence for lithic projectile injuries: improving identification of an under-recognised phenomenon. Journal of Archaeological Science 34, 540-553. 
Stiner, M., 2002. Carnivory, coevolution, and the geographic spread of the genus Homo, Journal of Archaeological Ressearch 10, 1-63.

Stodiek, U., 1991. Erste Ergebnisse experimenteller Untersuchungen von Gewiehgeschoßspitzen des Magdalénien. Archäologische Mitteilungen aus Nordwestdeutschland Beiheft 6, 245-256.

Stodiek, U., 1993. Zur Technologie der Jungpaläolithischen Speerschleuder. Eine Studie auf der Basis Archäologischer, Ethnologischer und Experimenteller Erkenntnisse. Archaeologia Venatoria, Tübingen.

Stodiek, U., 2000. Preliminary results of an experimental investigation of Magdalenian antler points, in: Bellier, C., Cattelain, P., Otte, M. (Eds.), La chasse dans la préhistoire. Société royale belge d'Anthropologie et de Préhistoire/Service de Préhistoire de l'université de Liège/Centre d'études et de documentation archéologiques, Bruxelles, pp. 70-78.

Ströbel, R., 1959. Tardenoisspitze in einem Bovidenknochen von Schwenningen am Neckar. Fundberichte aus Schwaben 15, 103-106.

Villa, P., d'Errico, F., 2001. Bone and ivory points in the Lower and Middle Paleolithic of Europe. Journal of Human Evolution 41, 69-112.

Zenin, V.N., Leshchinskiy, S.V., Zolotarev, K.V., Grootes, P.M., Nadeau, M.-J., 2006. Lugovskoe: Geoarchaeology and culture of a paleolithic site. Archaeology, Ethnology and Anthropology of Eurasia, 25, 41-53. 


\section{Figure captions}

Figure 1 : hafting of the experimental fork-based points. Left : experimental point and its shaft. Top right : the distal fork of the shaft is interlocked with the proximal fork of the point. Bottom right : the point is held in place with hide glue and red deer sinew.

Figure 2 : experimental impact traces - notches. a : rib, ox calf, bow shot, 2003. b : radio-ulna, fallow deer, spearthrower shot, 2004.

Figure 3 : experimental impact traces - puncture with crack and embedding. Distal extremity of humerus, ox calf, bow shot, 2003.

Figure 4: experimental impact traces - perforations. a : with crack and embedding; radio-ulna, ox calf, spearthrower shot, 2003. b: with crack; rib, fallow deer, spearthrower shot, 2004.

Figure 5 : experimental impact traces - scapula with seven perforations, three of them with embedding of the point (ox calf, bow shots, 2003).

Figure 6: experimental impact traces - perforations with cracks (the bone actually suffered two very close impacts); proximal extremity of tibia, fallow deer, bow shots, 2004.

Figure 7 : multiple fractures of an experimental projectile tip. The shaft (bottom), foreshaft (middle) and point (top) of this atlatl-propelled spear were fractured by a single impact on the proximal part of a fallow deer right humerus. The humerus showed no macroscopical damage.

Figure 8 : experimental impact traces - scapula with five perforations, all of them with cracks. The four cracks on the distal part splintered the bone (fallow deer, spearthrower shots, 2004).

Figure 9 : rib fragment of a medium-sized ungulate (Isturitz, Grande salle, Upper Magdalenian, layer I/F1) and close-up view of the notch.

Figure 10: left scapula of a deer (Isturitz, salle Saint-Martin, Middle Magdalenian, layer SI) and close-up view of the perforation. The white circles indicate the negative removals of bone discs (rondelles).

Figure 11: awl made from an ulna (La Vache, salle Monique, Upper Magdalenian) and close-up view of the notch. The white frame indicates the part worked by scraping. 

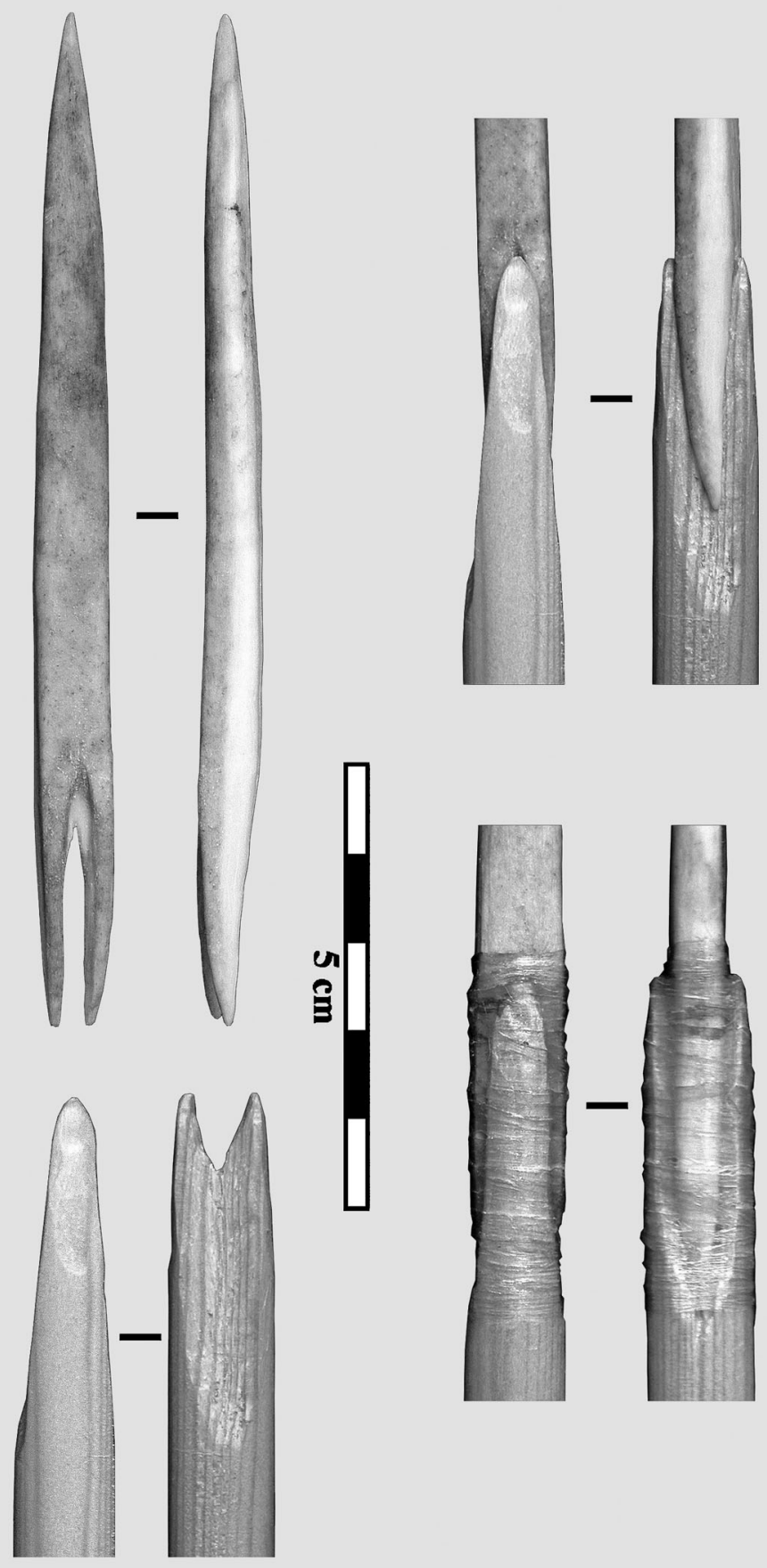


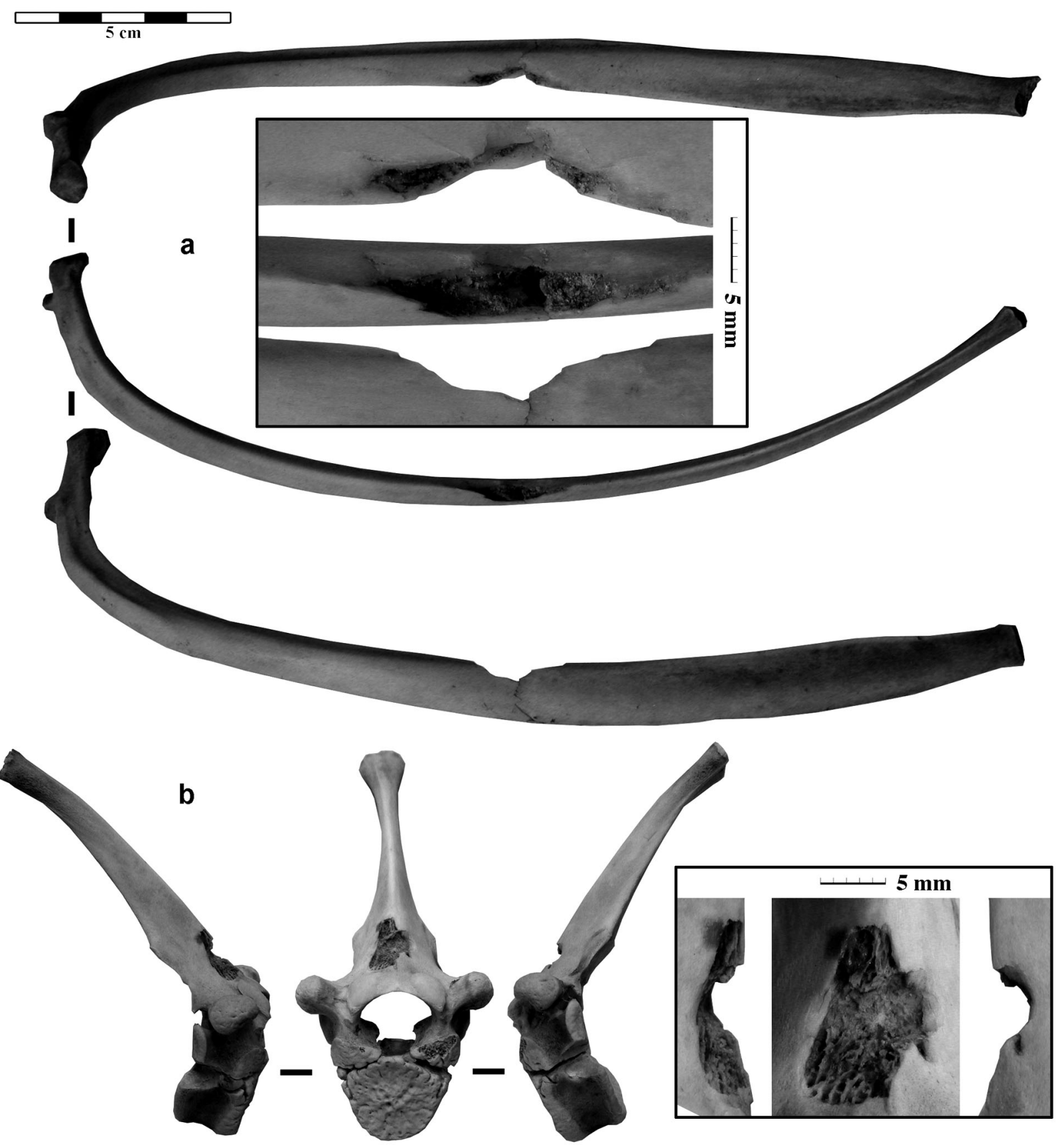





$$
18=
$$





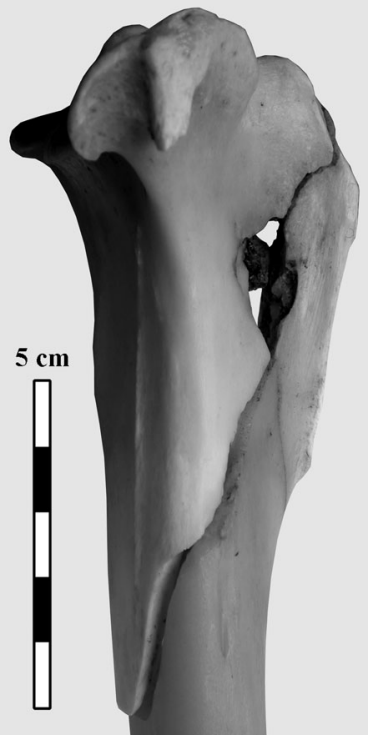



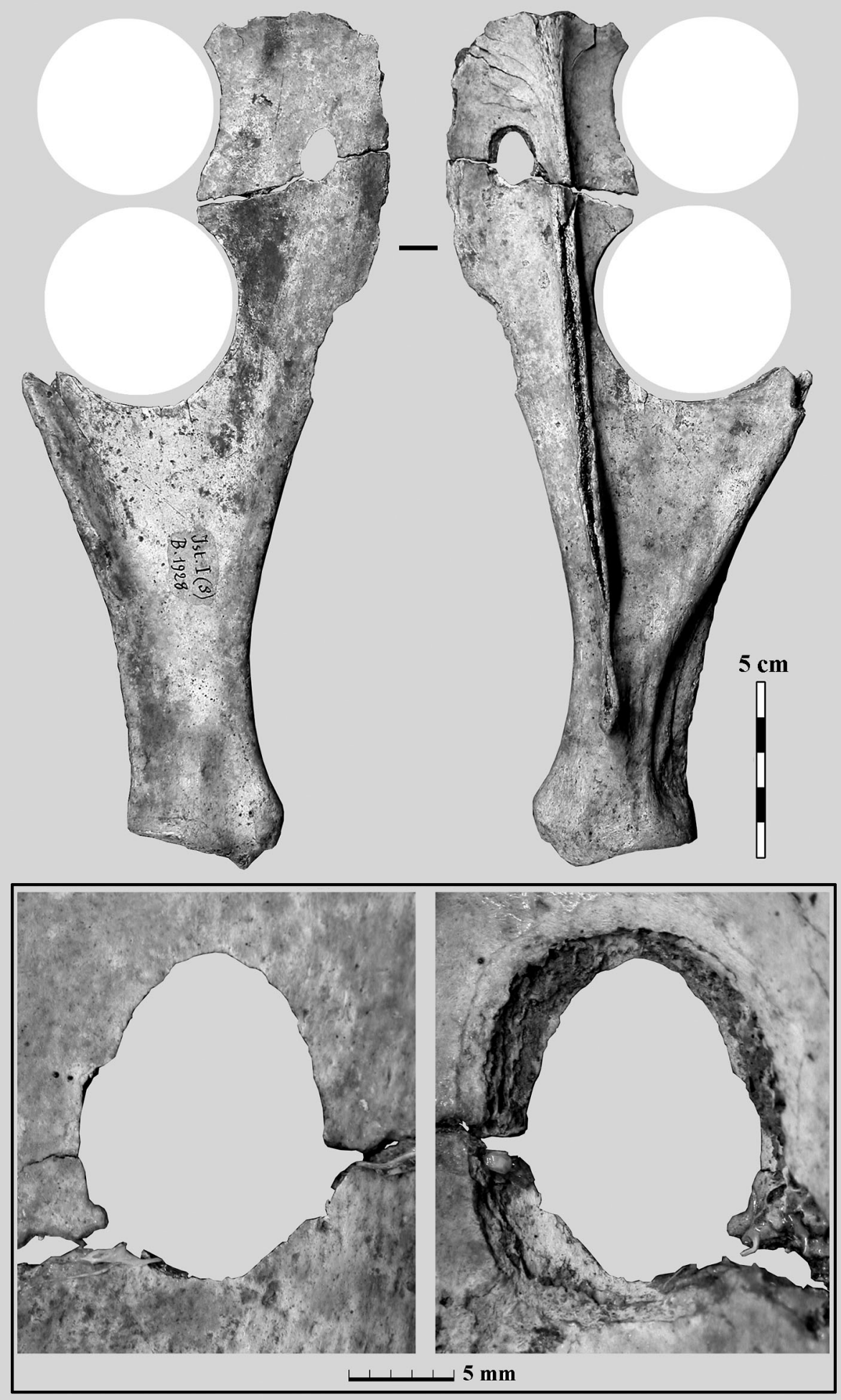

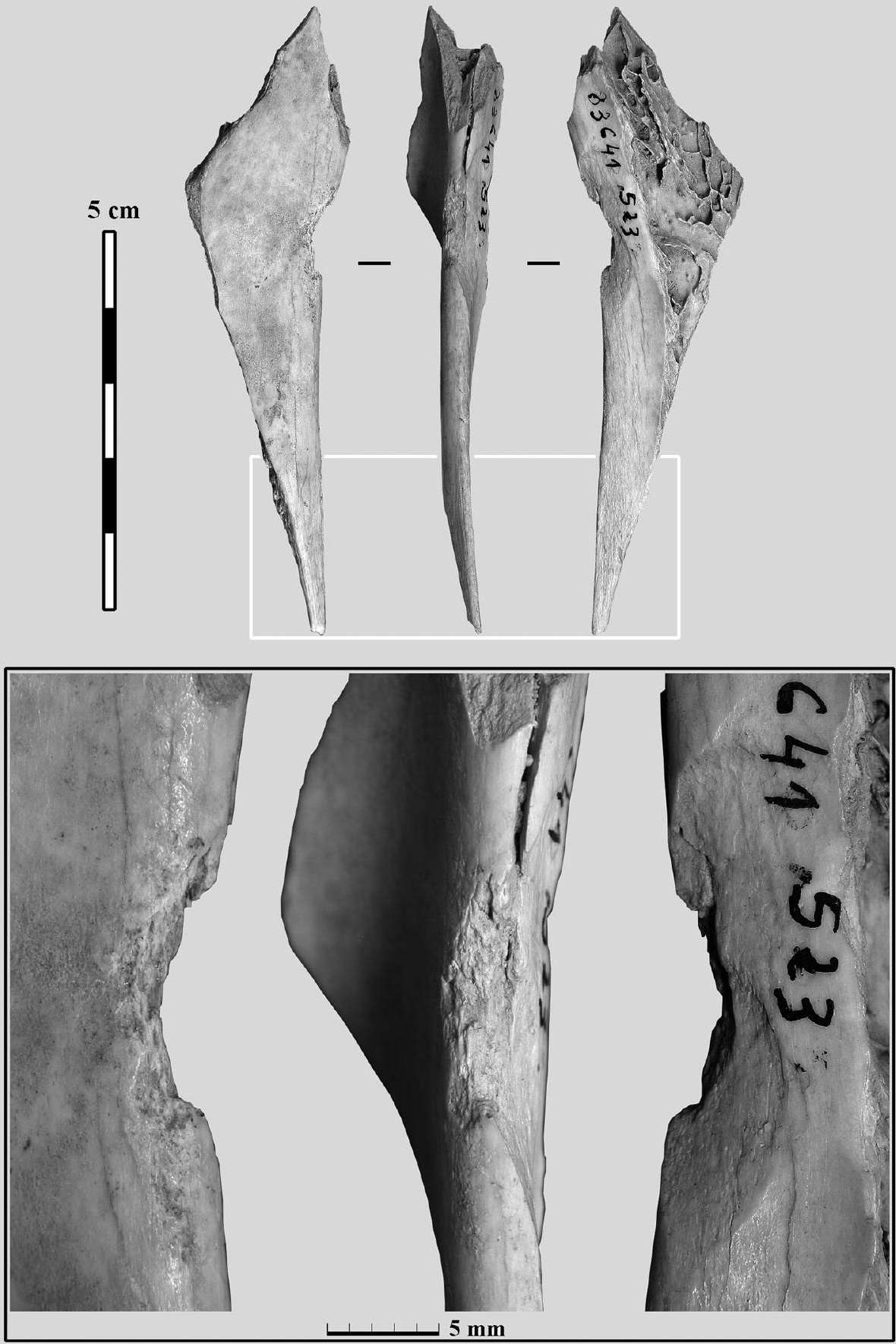
Table 1

Characteristics of the archaeological and experimental points. All dimensions are in millimeters.

\begin{tabular}{lllllll}
\hline & \multicolumn{3}{l}{ Fork-based points } & & \multicolumn{3}{c}{ Double-beveled points } \\
\cline { 2 - 4 } & Archeo & Exp Sp & Exp Ar & Archeo & Exp Sp & Exp Ar \\
\hline N of specimens & 419 & 45 & 33 & 95 & 9 & 9 \\
Total length & 100.3 & 106.7 & 106.2 & 91.8 & 89.6 & 90.8 \\
Length of mesio-distal part & 69.2 & 73.8 & 74.3 & 60.6 & 60.0 & 62.3 \\
Length of fork/bevel & 33.7 & 32.9 & 31.9 & 29.9 & 29.7 & 28.4 \\
Maximum width & 9.3 & 9.3 & 9.2 & 7.9 & 8.1 & 7.7 \\
Maximum thickness & 7.1 & 6.7 & 6.4 & 7.0 & 7.2 & 6.7 \\
Mass (g) & - & 5.7 & 5.5 & - & 5.2 & 5.0 \\
\hline
\end{tabular}

Archeo $=$ archeological specimen; Exp Sp = experimental spear; Exp Ar = experimental arrow 
Table 2

Characteristics of the experimental arrows and spears used in 2003-2004. All dimensions are in centimeters.

\begin{tabular}{lllll}
\hline & \multicolumn{2}{l}{ Arrows } & \multicolumn{2}{l}{ Spears } \\
\cline { 2 - 4 } & 2003 & 2004 & 2003 & 2004 \\
\hline N of projectiles & 21 & 21 & 21 & 33 \\
Mean length & 89.0 & 80.0 & 250.0 & 250.0 \\
Diameter & 0.9 & 0.9 & 1.2 & 1.4 \\
Mean weight (g) & 34.0 & 31.0 & 157.0 & 193.0 \\
\hline
\end{tabular}


Table 3

Skeletal distribution of the different impact traces by species and weapon (bow, Spe $=$ spearthrower).

\begin{tabular}{|c|c|c|c|c|c|c|c|c|}
\hline \multirow[b]{2}{*}{ Skeletal part } & \multicolumn{2}{|c|}{ Ox calf } & \multicolumn{2}{|c|}{ Fallow deer } & \multicolumn{2}{|c|}{ Total marks } & \multirow[b]{2}{*}{ Tot. } & \multirow[b]{2}{*}{$\%$} \\
\hline & $\overline{\text { Bow }}$ & Spe. & Bow & Spe. & $\overline{\text { Bow }}$ & Spe. & & \\
\hline Head & 0 & 1 & 0 & 1 & 0 & 2 & 2 & 1.6 \\
\hline Cerv. vert. & 0 & 2 & 1 & 9 & 1 & 11 & 12 & 9.4 \\
\hline Tho. + lum. vert. & 9 & 4 & 5 & 19 & 14 & 23 & 37 & 29.1 \\
\hline Rib & 7 & 4 & 7 & 10 & 14 & 14 & 28 & 22.0 \\
\hline Sternum & 2 & 0 & 1 & 2 & 3 & 2 & 5 & 3.9 \\
\hline Scapula & 7 & 4 & 2 & 7 & 9 & 11 & 20 & 15.7 \\
\hline Humerus & 6 & 1 & 0 & 2 & 6 & 3 & 9 & 7.1 \\
\hline Radius-ulna & 0 & 2 & 0 & 1 & 0 & 3 & 3 & 2.4 \\
\hline Innominate & 0 & 0 & 1 & 4 & 1 & 4 & 5 & 3.9 \\
\hline Sacrum & 0 & 0 & 1 & 3 & 1 & 3 & 4 & 3.1 \\
\hline Tibia & 0 & 0 & 2 & 0 & 2 & 0 & 2 & 1.6 \\
\hline Total & 31 & 18 & 20 & 58 & 51 & 76 & 127 & 100.0 \\
\hline
\end{tabular}


Table 4

Experiments 2003: Impact traces on the bones of the ox calf shot with a spearthrower.

\begin{tabular}{llllllllll}
\hline Skeletal parts & $\mathrm{N}$ & $\mathrm{Pu}$ & $\mathrm{Pu}+\mathrm{C}$ & $\mathrm{Pu}+\mathrm{C}+\mathrm{E}$ & $\mathrm{P}$ & $\mathrm{P}+\mathrm{C}$ & $\mathrm{P}+\mathrm{E}$ & $\mathrm{P}+\mathrm{C}+\mathrm{E}$ & Tot. \\
\hline Head & 0 & 0 & 0 & 0 & 1 & 0 & 0 & 0 & 1 \\
Cerv ver & 0 & 0 & 0 & 0 & 0 & 0 & 1 & 1 & 2 \\
Tho ver & 2 & 0 & 0 & 0 & 0 & 1 & 0 & 0 & 3 \\
Lum ver & 0 & 0 & 0 & 0 & 1 & 0 & 0 & 0 & 1 \\
Rib & 3 & 0 & 0 & 0 & 0 & 1 & 0 & 0 & 4 \\
Scapula & 0 & 0 & 0 & 1 & 1 & 0 & 0 & 2 & 4 \\
Humerus & 0 & 0 & 0 & 0 & 0 & 1 & 0 & 0 & 1 \\
Radius & 0 & 0 & 0 & 0 & 0 & 0 & 0 & 1 & 1 \\
Ulna & 0 & 0 & 0 & 0 & 0 & 0 & 0 & 1 & 1 \\
Total & 5 & 0 & 0 & 1 & 3 & 3 & 1 & 5 & 18 \\
\hline
\end{tabular}

$\mathrm{N}=$ notch; $\mathrm{Pu}=$ puncture $\mathrm{P}=$ perforation; $\mathrm{C}=$ crack $\mathrm{E}=$ embedding. 
Table 5

Experiments 2003: Impact traces on bones of the ox calf shot with a bow.

\begin{tabular}{llllllllll}
\hline Skeletal parts & $\mathrm{N}$ & $\mathrm{Pu}$ & $\mathrm{Pu}+\mathrm{C}$ & $\mathrm{Pu}+\mathrm{C}+\mathrm{E}$. & $\mathrm{P}$ & $\mathrm{P}+\mathrm{C}$ & $\mathrm{P}+\mathrm{E}$ & $\mathrm{P}+\mathrm{C}+\mathrm{E}$ & Tot. \\
\hline Tho ver & 5 & 1 & 0 & 0 & 0 & 3 & 0 & 0 & 9 \\
Rib & 3 & 0 & 0 & 0 & 1 & 3 & 0 & 0 & 7 \\
Sternum & 0 & 1 & 1 & 0 & 0 & 0 & 0 & 0 & 2 \\
Scapula & 0 & 0 & 0 & 0 & 3 & 1 & 3 & 0 & 7 \\
Humerus & 1 & 1 & 0 & 1 & 1 & 1 & 0 & 1 & 6
\end{tabular}

$\begin{array}{llllllllll}\text { Total } & 9 & 3 & 1 & 1 & 5 & 8 & 3 & 1 & 31\end{array}$

$\mathrm{N}=$ notch; $\mathrm{Pu}=$ puncture; $\mathrm{P}=$ perforation; $\mathrm{C}=$ crack; $\mathrm{E}=$ embedding. 
Table 6

Experiments 2004: Impact traces on the bones of the fallow deer shot with a spearthrower.

\begin{tabular}{llllllll}
\hline Skeletal parts & $\mathrm{N}$ & $\mathrm{N}+\mathrm{C}$ & $\mathrm{Pu}$ & $\mathrm{P}$ & $\mathrm{P}+\mathrm{C}$ & $\mathrm{P}+\mathrm{E}$ & Tot. \\
\hline Head & 0 & 0 & 0 & 0 & 1 & 0 & 1 \\
Cerv ver & 6 & 0 & 0 & 2 & 0 & 1 & 9 \\
Tho + lum ver & 9 & 0 & 1 & 6 & 3 & 0 & 19 \\
Rib & 2 & 2 & 2 & 0 & 4 & 0 & 10 \\
Sternum & 1 & 0 & 0 & 1 & 0 & 0 & 2 \\
Scapula & 0 & 0 & 0 & 2 & 5 & 0 & 7 \\
Humerus & 2 & 0 & 0 & 0 & 0 & 0 & 2 \\
Radius-ulna & 1 & 0 & 0 & 0 & 0 & 0 & 1 \\
Innominate & 2 & 0 & 0 & 2 & 0 & 0 & 4 \\
Sacrum & 0 & 0 & 0 & 3 & 0 & 0 & 3
\end{tabular}

Total $\begin{array}{lllllll}23 & 2 & 3 & 16 & 13 & 1 & 58\end{array}$

$\mathrm{N}=$ notch; $\mathrm{Pu}=$ puncture; $\mathrm{P}=$ perforation; $\mathrm{C}=$ crack; $\mathrm{E}=$ embedding. 
Table 7

Experiments 2004: Impact traces on the bones of the fallow deer shot with a bow.

\begin{tabular}{llllllll}
\hline Skeletal parts & $\mathrm{N}$ & $\mathrm{N}+\mathrm{C}$ & $\mathrm{Pu}$. & $\mathrm{P}$ & $\mathrm{P}+\mathrm{C}$ & $\mathrm{P}+\mathrm{E}$ & Tot. \\
\hline Cerv ver. & 0 & 1 & 0 & 0 & 0 & 0 & 1 \\
Tho + lum ver & 4 & 0 & 0 & 1 & 0 & 0 & 5 \\
Rib & 3 & 3 & 0 & 0 & 1 & 0 & 7 \\
Sternum & 1 & 0 & 0 & 0 & 0 & 0 & 1 \\
Scapula & 0 & 0 & 0 & 0 & 2 & 0 & 2 \\
Innominate & 1 & 0 & 0 & 0 & 0 & 0 & 1 \\
Sacrum & 0 & 0 & 0 & 0 & 1 & 0 & 1 \\
Tibia & 0 & 0 & 0 & 0 & 2 & 0 & 2 \\
& & & & & & & \\
Total & 9 & 4 & 0 & 1 & 6 & 0 & 20 \\
\hline
\end{tabular}

$\mathrm{N}=$ notch; $\mathrm{Pu}=$ puncture; $\mathrm{P}=$ perforation; $\mathrm{C}=$ crack; $\mathrm{E}=$ embedding. 
Table 8

Impact traces by species.

\begin{tabular}{|c|c|c|c|c|c|c|c|c|}
\hline \multirow[b]{2}{*}{ Target species } & \multicolumn{2}{|c|}{ Notch } & \multicolumn{2}{|c|}{ Puncture } & \multicolumn{2}{|c|}{ Perforation } & \multicolumn{2}{|c|}{$\underline{\text { Total }}$} \\
\hline & $\mathrm{N}$ & $\%$ & $\mathrm{~N}$ & $\%$ & $\mathrm{~N}$ & $\%$ & $\mathrm{~N}$ & $\%$ \\
\hline Ox calf & 14 & 28.6 & 6 & 12.2 & 29 & 59.2 & 49 & 100.0 \\
\hline Fallow deer & 38 & 48.7 & 3 & 3.8 & 37 & 47.4 & 78 & 100.0 \\
\hline Total & 52 & 40.9 & 9 & 7.1 & 66 & 52.0 & 127 & 100.0 \\
\hline
\end{tabular}


Table 9

Skeletal distribution of the different impact traces by species.

\begin{tabular}{lllllll}
\hline & \multicolumn{2}{l}{ Ox calf } & & \multicolumn{3}{l}{ Fallow deer } \\
\cline { 3 - 5 } Skeletal part & Notch & Puncture & Perforation & Notch & Puncture & Perforation \\
\hline Head & 0 & 0 & 1 & 0 & 0 & 1 \\
Cerv ver & 0 & 0 & 2 & 7 & 0 & 3 \\
Tho + lum ver & 7 & 1 & 5 & 13 & 1 & 10 \\
Sacrum & 0 & 0 & 0 & 0 & 0 & 4 \\
Sternum & 0 & 2 & 0 & 2 & 0 & 1 \\
Rib & 6 & 0 & 5 & 10 & 2 & 5 \\
Innominate & 0 & 0 & 0 & 3 & 0 & 2 \\
Scapula & 0 & 1 & 10 & 0 & 0 & 9 \\
Humerus & 1 & 2 & 4 & 2 & 0 & 0 \\
Radius-ulna & 0 & 0 & 2 & 1 & 0 & 0 \\
Tibia & 0 & 0 & 0 & 0 & 0 & 2 \\
Total & 14 & 6 & 29 & 38 & 3 & 37 \\
\hline
\end{tabular}


Table 10

Number of point embeddings per type of impact traces and species.

Target species Notch Puncture Perforation Total

$\begin{array}{lllll}\text { Ox calf } & 0 / 14 & 2 / 6 & 10 / 29 & 12 / 49\end{array}$

\begin{tabular}{lllll} 
Fallow deer & $0 / 38$ & $0 / 3$ & $1 / 37$ & $1 / 78$ \\
\hline
\end{tabular} 
Table 11

Distribution of impact traces by anatomical region

\begin{tabular}{lllll}
\hline Skeletal part & Notch & Puncture & Perforation & Total \\
\hline Head & 0 & 0 & 2 & 2 \\
Cerv + lumb ver & 27 & 2 & 24 & 53 \\
Tho ver + sternum & 18 & 4 & 11 & 33 \\
Scapula + innominate & 3 & 1 & 21 & 25 \\
Long bones & 4 & 2 & 8 & 14 \\
& & & & \\
Total & 52 & 9 & 66 & 127 \\
\hline
\end{tabular}


Table 12

Survey of the published projectile impact traces on Paleolithic and Mesolithic faunal material.

\begin{tabular}{|c|c|c|c|c|c|c|c|c|}
\hline Site & Country & Archaeological context & Species & $\mathrm{N}$ trace & Bone & Trace & Emb fr & Reference \\
\hline Aldersro & Denmark & Mesolithic & Boar & 1 & Sku & $\mathrm{Pu}^{*}$ & Lithic & Noe-Nygaard, 1974 \\
\hline Aldersro & Denmark & Mesolithic & Boar & 1 & Elb & $\mathrm{Pu}^{*}$ & Lithic & Noe-Nygaard, 1974 \\
\hline Åmose bog & Denmark & Mesolithic & Red deer & 1 & Sca & $\mathrm{P}^{*}$ & None & Noe-Nygaard, 1974 \\
\hline Combe-Buisson & France & Aurignacian & Large ung. & 1 & $?$ & $\mathrm{Pu}$ & Osseous & Moirenc et al., 1921 \\
\hline Combe-Saunière & France & Solutrean & Horse & 1 & Sca & $\mathrm{Pu}$ & Lithic & Castel, 1999 \\
\hline Grænge mose & Denmark & Mesolithic & Aurochs & 1 & Sca & $\mathrm{P}$ & None & Noe-Nygaard, 1974 \\
\hline Grotte des Eyzies & France & Magdalenian & Reindeer & 1 & Ver & $\mathrm{P}$ & Lithic & Lartet \& Christy, 1864 \\
\hline Grotte du Bichon & Switzerl. & Final Upper Paleolithic & B bear & 1 & Ver & $\mathrm{Pu}$ & Lithic & Morel, 1998 \\
\hline Henriksholm & Denmark & Mesolithic & Swan & 1 & Hum & $\mathrm{Pu}$ & Lithic & Noe-Nygaard, 1974 \\
\hline Hohle Fels & Germany & Early Gravettian & $\mathrm{C}$ bear & 1 & Ver & $\mathrm{Pu}$ & Lithic & Münzel \& Conard, 200 \\
\hline Jordløse & Denmark & Mesolithic & Red deer & 2 & Sca & $\mathrm{P}^{*}$ & None & Noe-Nygaard, 1974 \\
\hline Klampenborg & Denmark & Mesolithic & $?$ & 1 & $?$ & $\mathrm{Pu}$ & Lithic & Noe-Nygaard, 1974 \\
\hline Kokorevo I & Russia & Upper Paleolithic & Bison & 1 & Sca & $\mathrm{P}$ & Osseous & Boriskowski, 1965 \\
\hline Kongemosen & Denmark & Mesolithic & Red deer & 2 & Sca & $\mathrm{P}$ & None & Noe-Nygaard, 1974 \\
\hline Kongemosen & Denmark & Mesolithic & Red deer & 1 & Hum & $\mathrm{P}$ & Lithic & Noe-Nygaard, 1974 \\
\hline Kongemosen & Denmark & Mesolithic & Roe deer & 1 & Sca & $\mathrm{P}^{*}$ & None & Noe-Nygaard, 1974 \\
\hline Kongemosen & Denmark & Mesolithic & Roe deer & 1 & Sca & $\mathrm{P}$ & None & Noe-Nygaard, 1974 \\
\hline La Garma & Spain & Magdalenian & Horse & 1 & Man & $\mathrm{Pu}$ & Lithic & Arias Cabal et al., 2005 \\
\hline Lugovskoe & Russia & Upper Paleolithic & Mammoth & 1 & Ver & $\mathrm{Pu}$ & Lithic & Zenin et al. 2006 \\
\hline
\end{tabular}

The following specimens were excluded because of the uncertain identification of the projectile traces: Frøslev mose, Fuglekjær, Hastrup mose, Nørre Sengelse, Slagslunde, Søborg mose (all after Noe-Nygaard, 1974), High Furlong (Hallam et al. 1973, Noe-Nygaard 1975), la Garenne (Allain, 1952) and Pataud (Bouchud, 1975).

Species: Large ung = Large ungulate; $\mathrm{B}$ bear $=$ brown bear; $\mathrm{C}$ bear $=$ cave bear.

Bone: Elb = "elbow" (after the published data); Hum = humerus; Man = mandible; Pel = pelvis; Sca = scapula; Ver = vertebra.

Trace: $\mathrm{Pu}=$ puncture; $\mathrm{P}=$ perforation; $\mathrm{Emb}$ fr $=$ Embedded fragment.

Var = varied (i.e., different bones or type of impact traces).

* indicates lesions with signs of healing. 
Table 12 continued

Survey of the published projectile impact traces on Paleolithic and Mesolithic faunal material.

\begin{tabular}{|c|c|c|c|c|c|c|c|c|}
\hline Site & Country & Archeological context & Species & $\mathrm{N}$ trace & Bone & Trace & Emb fr & Reference \\
\hline Maglelyng & Denmark & Mesolithic & Red deer & 2 & Rib & $\mathrm{Pu}^{*}$ & Lithic & Noe-Nygaard, 1974 \\
\hline Maglemose & Denmark & Mesolithic & Boar & 1 & Sca & $\mathrm{P}$ & None & Noe-Nygaard, 1974 \\
\hline Meiendorf & Germany & Hamburgian & Reindeer & 5 & Var & Var & Lithic & Bratlund, 1990 \\
\hline Montfort & France & Azilian & Deer & 1 & Ver & $\mathrm{P}$ & Lithic & Régnault, 1893 \\
\hline Ringkloster & Denmark & Mesolithic & Red deer & 1 & Ver & $\mathrm{P}$ & Lithic & Noe-Nygaard, 1974 \\
\hline Ringkloster & Denmark & Mesolithic & Boar & 1 & Ver & $\mathrm{P}$ & $?$ & Noe-Nygaard, 1974 \\
\hline Schussenquelle & Germany & Magdalenian & Reindeer & 1 & Sca & $\mathrm{P}$ & Lithic & Schuler, 1994 \\
\hline Schwenningen & Germany & Mesolithic & Aurochs & 1 & Pel & $\mathrm{Pu}$ & Lithic & Ströbel, 1959 \\
\hline Star Carr & U.K. & Mesolithic & Red deer & 1 & Sca & $\mathrm{P}^{*}$ & None & Noe-Nygaard, 1975 \\
\hline Star Carr & U.K. & Mesolithic & Elk & 1 & Sca & $\mathrm{P}^{*}$ & None & Noe-Nygaard, 1975 \\
\hline Stellmoor & Germany & Hamburgian, Ahrensburgian & Reindeer & 32 & Var & Var & Lithic & Bratlund, 1990 \\
\hline Sværdborg & Denmark & Mesolithic & Boar & 1 & Sca & $\mathrm{P}^{*}$ & None & Noe-Nygaard, 1974 \\
\hline Svenstrup & Denmark & Mesolithic & Red deer & 1 & Rib & $\mathrm{Pu}^{*}$ & Lithic & Noe-Nygaard, 1974 \\
\hline Veyrier & France & Magdalenian & Reindeer & 1 & Sca & $\mathrm{P}$ & None & Sauter, 1985 \\
\hline Vig & Denmark & Mesolithic & Aurochs & 1 & Rib & $\mathrm{Pu}^{*}$ & Lithic & Noe-Nygaard, 1974 \\
\hline Vig & Denmark & Mesolithic & Aurochs & 1 & Rib & $\mathrm{Pu}$ & Lithic & Noe-Nygaard, 1974 \\
\hline Vig & Denmark & Mesolithic & Aurochs & 1 & Sca & $\mathrm{P}$ & None & Noe-Nygaard, 1974 \\
\hline
\end{tabular}

The following specimens were excluded because of the uncertain identification of the projectile traces: Frøslev mose, Fuglekjær, Hastrup mose, Nørre Sengelse, Slagslunde, Søborg mose (all after Noe-Nygaard, 1974), High Furlong (Hallam et al. 1973, Noe-Nygaard 1975), la Garenne (Allain, 1952) and Pataud (Bouchud, 1975).

Species: Large ung = Large ungulate; $\mathrm{B}$ bear = brown bear; $\mathrm{C}$ bear = cave bear.

Bone: $\mathrm{Elb}=$ "elbow" (after the published data); Hum = humerus; Man = mandible; Pel = pelvis; Sca = scapula; Ver = vertebra.

Trace: $\mathrm{Pu}=$ puncture; $\mathrm{P}=$ perforation; $\mathrm{Emb} \mathrm{fr}=$ Embedded fragment.

$\operatorname{Var}=$ varied (i.e., different bones or type of impact traces).

* indicates lesions with signs of healing. 